\title{
The Problem Change Function of Heritage Building at the Old Cities in Central Java
}

\author{
Edy Darmawan
}

Titien Woro Murtini

Architecture Department, Engineering Faculty, Diponegoro University

\begin{abstract}
The old city is the commercial center in Semarang City in The Dutch Government. It can be seen from the buildings a relic history of hotel, warehouse, and also religious buildings. Almost all this building still exist, but they were unable to function properly. Even some buildings are used as shed byt the rightful owner of the land. The use of building be a barn it gives the impression slum and not safe to the old city. The flood problem in the old city who lack of after causing the quality of the environment in the old city get worse. This condition certainly disturb the face of the city and made the building worthless again. If managed well, those buildings in ancient old city this can be icon historic for Semarang City. One concept which can be applied to overcome these issues is to conservation old buildings to be new functions as the best possible. This concept chosen because see that function old buildings are no right again when maintained, so we needed sought the use of more worthy economically for old buildings historic not to stopped and remain maintained. The purpose of this research is studying characteristic model the concept of conservation old buildings and produce model design as an application from the concept of conservation of any old buildings. To achieve this aim will be used a methodology qualitative descriptive which can explain problem indetail and described potentials. The result of this research in the form of a model design that can be applied in ancient building, so can improve their quality, both in terms of social, economic, and culturally.
\end{abstract}

Keywords: Change Function, Heritage Building, Old Cities.

\section{Introduction}

Items of Cultural Heritage, a site is a location which contains or is thought to contain items of cultural heritage including the surroundings required to ensure its safety. Items of Cultural Heritage are artifacts made by man, moveable or immovable, individually or in groups, or parts thereof or remains thereof, which are at least 50 years of age, or represent a specific period at least 50 years of age, and a natural object which are considered to be of significant value to history, science and culture (The President of Indonesia Law No. 5/1992 regarding Cultural Heritage). Cultural items of cultural heritage are owned or inherited by descent or are heir looms, exist in sufficient numbers of any given type and a representative number are already owned by the state (The President of Indonesia Law No. 5/1992 regarding Cultural Heritage).

Heritage buildings consist of many functions as like officers, railway stations, ware housings, factories, hotels, housings, restaurants, stores, service officers, churches. At that period the building functions were really suitable for people's activities. And the site of building one mix use zone, everyone went to many functions building at the same zone. Therefore going one building to the others one accessible easily.

In the morning and in the afternoon the life of those areas were crowded by different attitude people, different activities, different ages, education and different employees. These zones were good condition in the morning and afternoon also in the night. Central Business District (CBD) usually arranged as mix use buildings as like in "Kota Lama Semarang-Indonesia, Amosfort-Amsterdam, Rotterdam, and Antwerp-Belgium. 


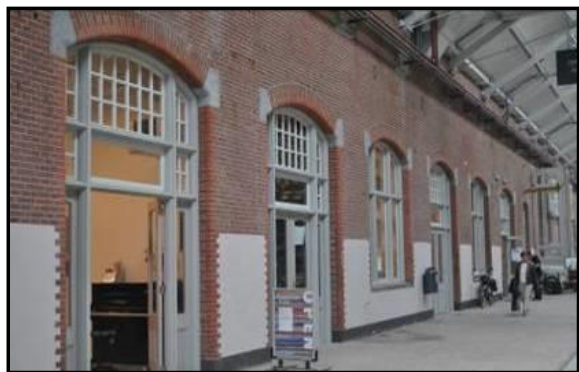

Source: (Darmawan, 2015).

Fig. 2. Changing function from central station in Amsterdam to be store

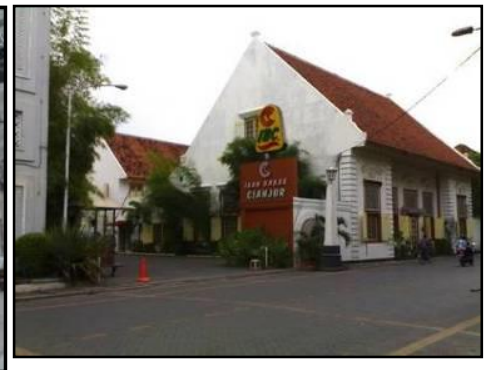

Source: (Darmawan, 2015).

Fig. 1. Changing function from court office in Kota Lama Semarang to be restaurant

\section{Review of Literature and Theoritical Framework}

\section{The Historical Building Conservation Theory}

In general, conservation can be defined as activities to care for, preserve sustainability, and preserve ancient and historic buildings to draw back the interest of the community to visit the area or building. Conservation activities are created because of the need to conserve degraded and damaged natural resources. The impact of such degradation creates fear and if not anticipated will endanger humanity, especially impact on the life of future generations. The existence of ancient buildings that are developing the story of history, way of life, culture, and civilization of society, providing opportunities for future generations to touch and live the struggle of his ancestors. Historical building preservation efforts are carried out to safeguard the history of the building, and to keep the building in order to be dedicated to future generations.

Snyder \& Catanese (1979) says that the conservation of historic buildings is basically an integral part of urban planning or "the urban planning". The conservation of historic buildings is closely related to three important things: (a) the historical development of the city, (b) the old town's historical area or environment and (c) the diverse context of "urban architecture" and the architectural style of the old historical building. Therefore, in the conservation activities there is always a common thread between the relics of architectural works with cultural values that took place in the community in the past. According to Mulyandari (2011), the criteria for conservation actions can be buildings or places that have aesthetic value, security, historical role, supporting an adjacent area that has important value and has special value or something important.

City development in a city area can be seen since the city area into an area inhabited and inhabited by community groups with urban style. The historical development of the city can be seen from the cultural forms of urban society from the simplest to the most sophisticated urban society. The cultural form of the people of this city will give birth or leave the works of architecture in the form of old buildings with historical value. Therefore, for big cities that are long-lived, the cultural influence of urban communities in an area will be of significant value in the aspect of historical values and cultural values for the society in the future. The old urban areas generally have architectural artefacts in the form of historic old buildings.

According to Papageorgiou as quoted by Mulyandari (2011), there are two criteria for determining a city or a part of a city area that can be categorized as a historic city area, namely (a) its uniqueness in its urban composition; (B) the state of the architectural quality and geographical locality, whereas a city that deserves conservation behavior is partly due to: (a) having a genuine urban structural composition; (B) have architectural qualities (both architectural monuments and certain interesting buildings) which indicate its urban development; $(\mathrm{C})$ have a sustainable social life.

\section{The Cultural of Conservation}

According to the certificate of Burra on 1984 on (Bappeda, 1988) the conservation is protected the cultural meaning of building or area for heritage in the future. For the cultural meaning is aesthetic review, historic, knowledge, social of environment building or cities. According J.C Catanese and J.C Snyder on (Bappeda, 1988) it's helped for last period and the future that review of cultural are consist of: 
Aesthetic: the shape, scale, colour, texture, and material also the smell, voice are depended to the place and function and relation of the landscape.

Historical aspect: consist of the community historic some place who has historic value related the hero even a historic events.

Knowledge value it's depend on the own interest, qualities and given information of values.

Social value; places that focus for activities such as spiritual, politic, cultural, weather from majority group or minority group.

Conservation is the main role of activities of heritage depend on the Burra charter for the conservation of place of cultural significance 1981 on (Bappeda, 1988).

Conservation is the process heritage of lace that cultural taken care very well. Conservation is concluded the preservation, restoration, reconstruction, adaptation and revitalization.

Preservation is the heritage that precise the original without changing and it's perfected the demolition.

Restoration/ Rehabilitation is returned of place or building with disappear the addition and to install the shape without use the new material.

Reconstruction is returning of the building at the similar original condition and uses the new or the old material.

Adaptation/ revitalization is change of the building to be usage the suitable function. The suitable function is usage that not needed the changing eventhough a little bit only.

Demolition is the damage of building that deterioration and dangerous condition and created the new style of the original.

\section{Kota Lama Semarang Area}

This area was a Dutch area called as the little Netherland in the colonials periods. At 19 - 20 century, this area had a function as trade center. The buildings here had a function as a town hall, castle, house, company, prison, etc. There are a lot of buildings has a basement (as a hiding place/ prison). Most of those building negleted. Some building has a new function as gallery, conference hall, cafe, church (Piandel, 2014). Most of those building also used as a tourism place (photography object and festival).

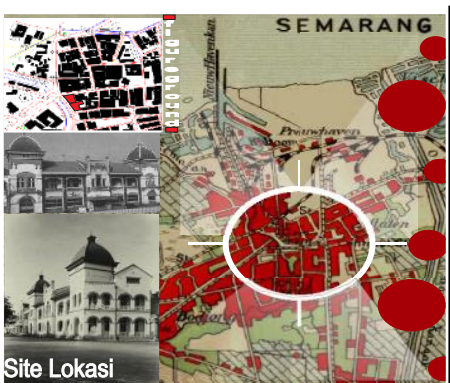

Source: (Piandel, 2014).

Fig 1: Location of Kota Lama Semarang.

\section{Techniques of Participations}

The clearly administration of community as important factor that often ignored whether on population, legalization of status, inventaritation physical facilities who have by communities whether government, therefore a lot of problem difficult happen, for performance the serial data accurate. Even we find out the data with many version were very confuse for need research or arrangement of planning program and urban planning for future and others program. This problem would be effect of the 
trust for people on the world to make corporation. The data occur at the laws community until center of government. The data have delivered trust way and simple would giving more uses for analysis or economic problem, social problem, cultural, political, defense and security. Therefore communities administration factor are techniques participation way for urban planning.

Political commitment is important thing at period reformation now days, for urban planning without legitimation and all statement that supported this program would be fail. Socialization interactive dialogue between planer, executive and legislative as representative of communities is very important need as techniques participation way for urban planning. The statement of many political elite would be affected to be success of urban planning program, and the short term or long term. Our community of Indonesia believed the paternalistic system that why thus political statement as effective way for successful.

For socialization step of urban planning, use the meetings with the community periodically. It's affected to adsorb the willingness and aspiration of communities for getting facilities of urban planning maximally. At this forum is expected design agreement that effective and efficient. The experiences at last periodically many programs that are not wiliness and aspiration of communities, and fail condition. Many idea from expert that publicated by mass media or electronic media or by book are participation technique way that very effective. Beside that thus ideas could be presented at the seminar forum, discussion, workshop or other forum.

For socialization of physical development program or effective urban planning true press release. At the press release the program would be explained detail and accurate to pass for pers. The information would be directed at the center way, therefore the community would be inform by urban communities.

\section{Research Design and Methods}

The method used in this research using qualitative descriptive approach method. This method is chosen because it is able to describe and describe field findings that aim to collect actual and detailed information, identify problems, make comparisons or evaluations, and determine what others do in the face of similar problems and learn from their experiences to plan And decisions in the future (Arikunto, 2006). Observations made on the Old Town area which is an area that has historic ancient buildings with Dutch colonial architectural style. Objects observed is the condition of the building is done by reviewing the elements supporting the character of the building, so it can be prepared redesign of the building.

\section{Discussion, Findings, and Interpretation}

\section{Kota Lama Semarang}

Just a view of those building that still functionate, the old city area active only at a view spot. At sendowo street (PT. Perkebunan \& Nusindo) that building are located across the Kali Semarang/ Mberok. Kali Semarang is an artificial river with 15-17 meters diameter. Function : city government has a plan to make this spot as a new tourism place in Kali Semarang ex: gondola rent, as a point of interest ( to attracted visitor).

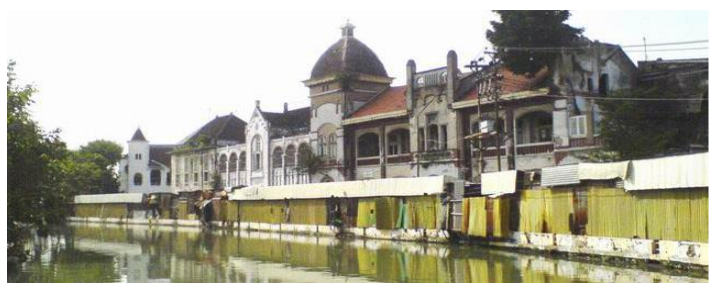

Source: (Piandel, 2014).

Fig 1: Existing of Heritage Building at Sendowo Street.

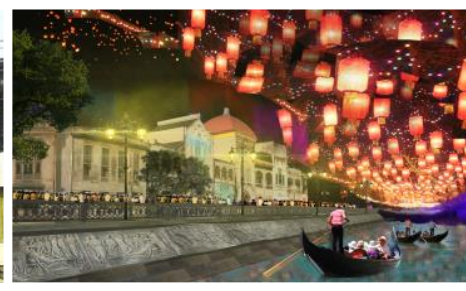

Source: (Piandel, 2014).

Fig 2: Redesign The Lively of Sendowo Street.

This location at Sendowo street (PT. Perkebunan \& Nusindo) has a new function as a supporting facility for city government's program at 2015. Function: this place has a function to atrract visitor in tourism segment and to reinforce the 
economic aspect (comercial), also used to maintaining the old city and open new jobs opportunities for people arround thie area.

Re-function: the function of PT. Perkebunan has changed as café \& resto, retail , with oldskool/ antique stuff center that bought from the communities around this area (to increasing people's income). Re-function: PT. Nusindo has a new function as museum, historic library \& art gallery (Piandel, 2014).
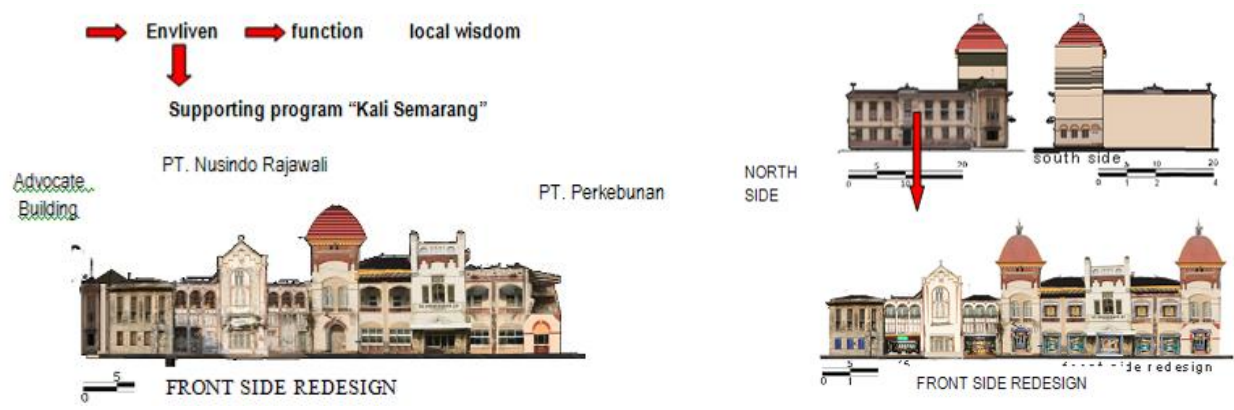

Source: (Piandel, 2014).

Fig 3: Redesign of Shortern Part.

We still have to obey the valid regulation to enliven the atmosphere of Sendowo Street at Semarang Old City. The building of Pt Perkebunan and PT Nusindo Rajawali, has "madya" status (allowed to get only small renovation treatment and the changes of façade isn't allowed) in valid regulation. So, on the way to enliven that building perfomance we onlu can:

Re-painting without changes the original base colour and cleaning the building area.

Re pro the existing floorplan without changes the building structures.

Make the new tower replica on the right side, without change any shape or colour of the exist building (PT. Perkebunan)

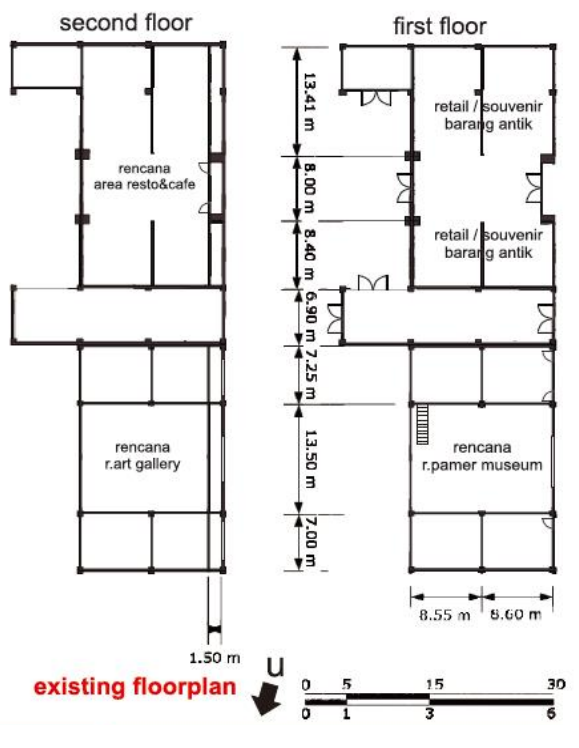

Source: (Piandel, 2014).

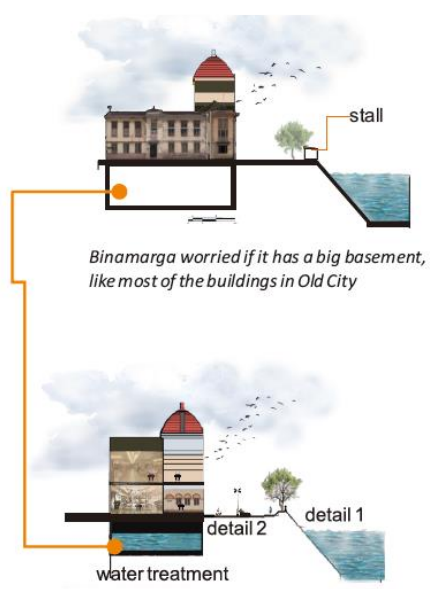

Source: (Ruci, et. al., 2014).

Fig 5: Redesign. 
Fig 4: Redesign and Refunction

Kota Lama include in eleven city in Indonesia that has an offical green concept area with president approval.

Water treatment details green area.

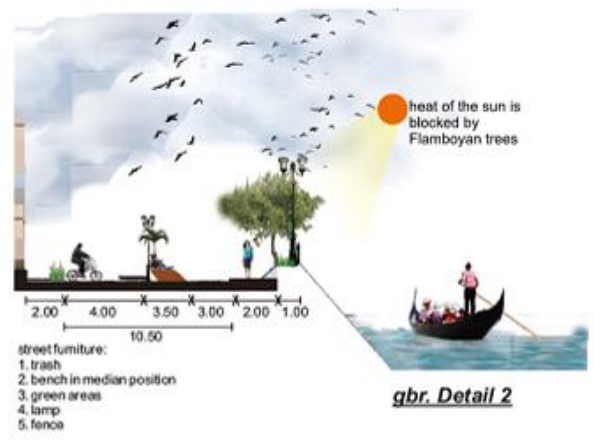

Source: (Ruci, et. al., 2014).

Fig 6: Refunction of Sendowo Street.

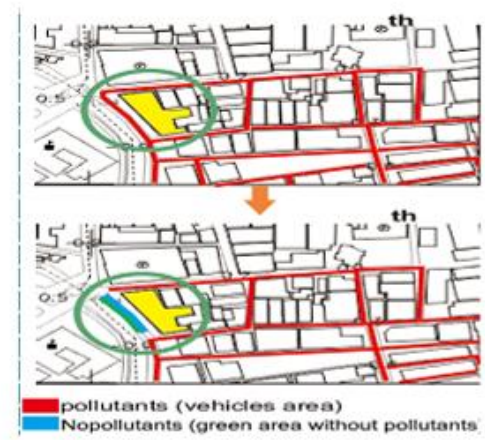

Source: (Ruci, et. al., 2014).

Fig 7: The Analysis Pollutants and No Pollutants Area.

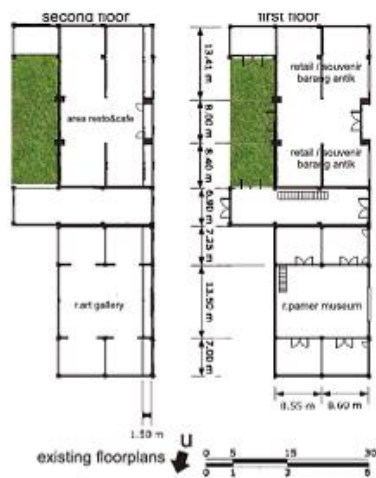

Source: (Ruci, et. al., 2014)

Fig 8: Refunction Floorplan.
Floorplan redesign can held by change and fixed the broken wall, the the rest problem can solved only by optimizing the space function organization and add some open space.

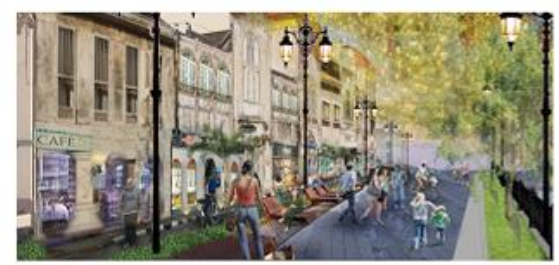

Source: (Piandel, 2014).

Fig 9: Eksterior Refunction of PT. Perkebunan and Nusindo.

\section{Kretek Mberok, Kota Lama Semarang}

The exact location of building which will be redesigned is near Kretek Mberok. Kretek Mberok is the famous bridge in Old Town Area. "Mberok" word comes from Dutch "brug", which means hanging bridge, it is like common bridge in Holland. 

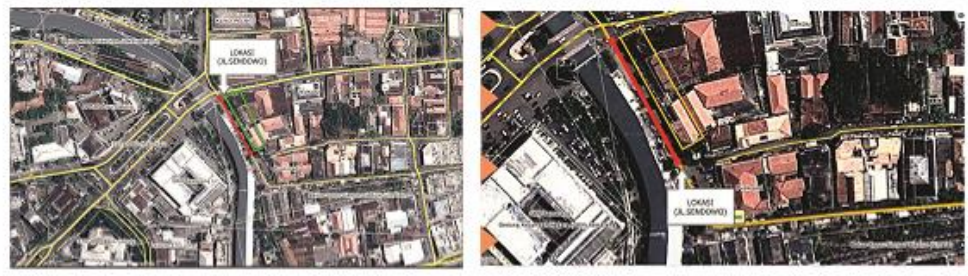

Source: (Ruci, et. al., 2014)

Fig 10: The Location Map of Kretek Mberok.

Old Town area in Semarang usually called Little Netherland, because those buildings constructed since the Dutch era. It has been becoming as mute witness of Dutch colonial Indonesia history for more than two centuries. Sadly most of the buildings are rundown, broken, or simply just facades of former glory. There are about 50 buildings that stand still and has tons of colonial history. The building that will be redesigned without eliminating the main identity of it, so the historic element will be kept to emphasis its characteristic. Specially to Semarang Old City Area itself. Problem in the past, Mberok River was the important part of these areas but slowly that river becoming ignored and dirty. Pedestrian way has malfunction as a place where the street vendors works, not a facility for pedestrian walks. The existence of public transportation around these objects actually makes this area into disorder (Ruci, et. al., 2014).

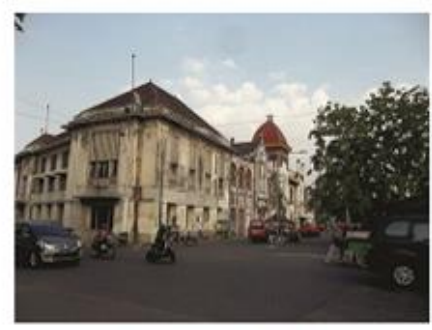

Source: (Ruci, et. al., 2014).

Fig 11: Existing of PT. Perkebunan and Nusindo Heritage Building.

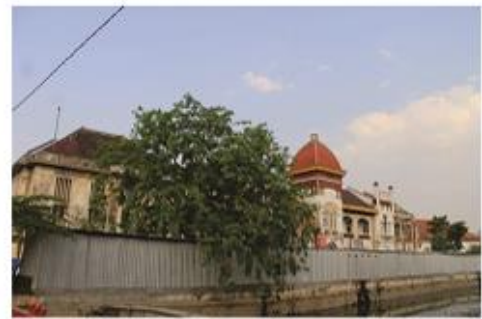

Source: (Ruci, et. al., 2014).

Fig 12: Location Area of Vendors in Front of The Heritage Building and Beside The River.

These old building looks neglecting and broken by pieces, whereas these areas are potential to be something beautiful and making Semarang be different than other cities. Few photos above show the situation around, even when the atmosphere still colonialist they still look not interesting to be visited.

\section{Redesign}

The building is currently an office, but somehow it looks unused. The idea of redesign planning is to change the function of this building as art gallery center. It will conclude café, art gallery, museum, and gift shop. We decided to involve the surrounding area for redesign planning because it linked each other. To feel what the museum represents is not only by what is inside but also what is happening outside. The building itself has two stories, and we do not can to add or reduce it so we keep it as two stories building. We only change the function and interior design and try to keep the real characteristic of this historical building especially the ornament (Ruci, et. al., 2014). 


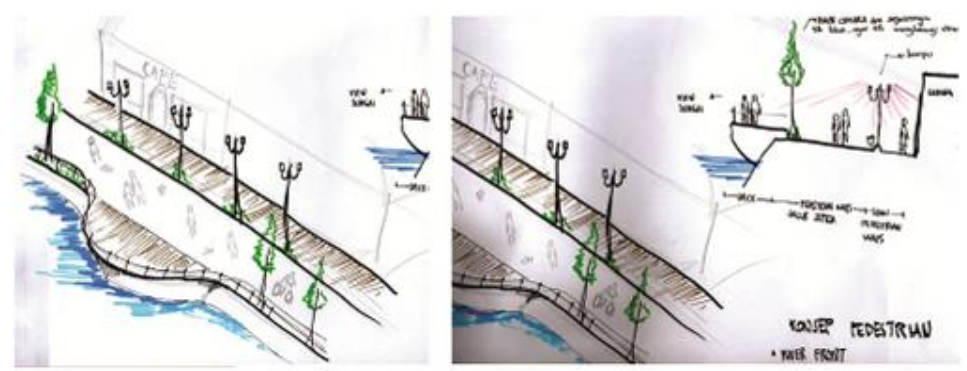

Source: (Ruci, et. al., 2014).

Fig 13: Sketch Redesign.
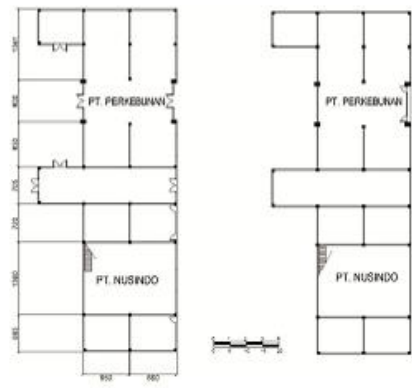

Source: (Ruci, et. al., 2014)

Fig 14: First floor and second floor.
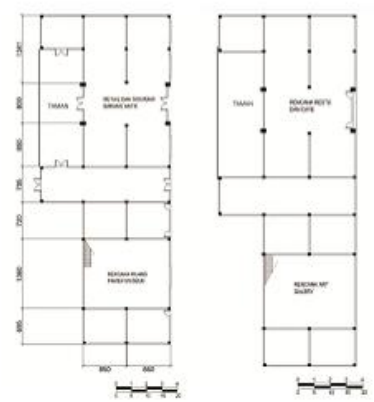

Source: (Ruci, et. al., 2014).

Fig 15: Redesign First floor and second floor.

This is a site plan of the building, and we can see how the neighborhood look like. Mberok river actually can be the main attraction of the area, so we include it for redesign plan by creating "river view space". Façade of this building has not changed at all. That because the maintain the figure of "Kota Lama" is used as a historical heritage tour in Semarang. Just cleaning and repainting that done on this building, so the building doesn't look dull (Ruci, et. al., 2014).

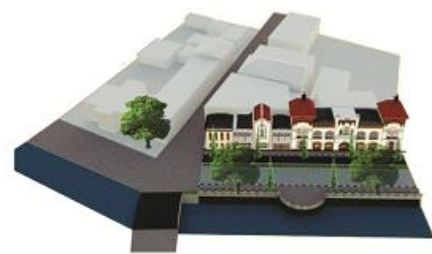

Source: (Ruci, et. al., 2014).

Fig 16: Site plan redesign.

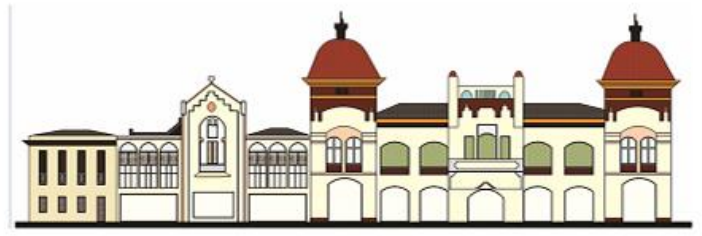

Source: (Ruci, et. al., 2014).

Fig 17: Facade redesign.

The exterior of the building is designed with pedestrian priority as "Kota Lama" tourists. Sendowo roads be an area that free of the vehicle. This will make the tourists comfortable to enjoy the atmosphere of "Kota Lama". 

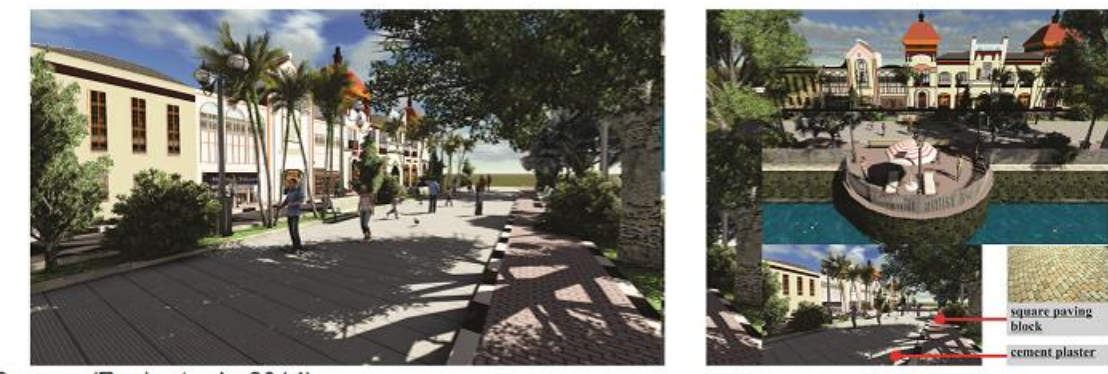

Source: (Ruci, et. al., 2014).

Fig 18: Exterior Redesign

The interior design is modern style, to keep the balance between vintage and modern. Calm colour is being the key in the rhythm of décor, except for the café which is using bold colour to encourage (Ruci, et. al., 2014).

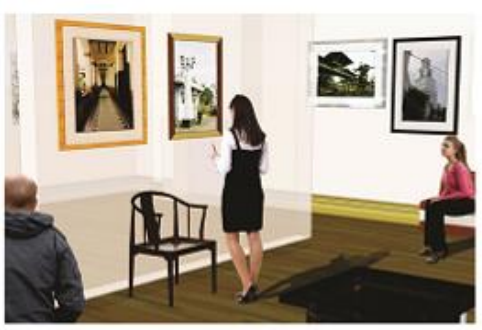

Source: (Ruci, et. al., 2014).

Fig 19: Interior Art Gallery.

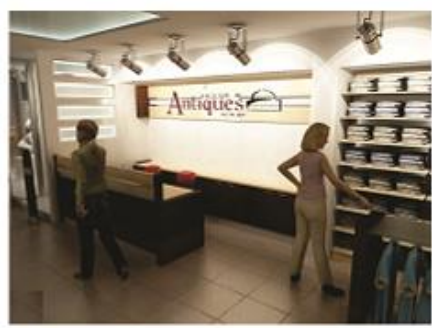

Source: (Ruci, et. al., 2014).

Fig 20: Interior Gift Shop.

\section{Revitalitation Lawang Sewu}

Lawang Sewu is located in the heart of the city, namely in the area of Tugu Muda Semarang, making it the building that will be seen by many people, this location was the one who also makes Lawang Sewu so strategic. Tugu Muda area is often used as public space, especially in the city of Semarang the youth spend a weekend night. This could be a great potential for Lawang Sewu building to be revitalized with a variety of functions that can accommodate community activities. Lawang Sewu not skyscraper which height is very prominent. However, for the size of the 2 storey building Lawang Sewu is high. Area is spacious and Europe style makes Lawang Sewu impressed magnificent. Lawang Sewu as one of the central point of tourism that very potential in Semarang and Central Java.

When viewed from the problem revitalization Lawang Sewu, probably the building is do iconic and save a lot of history and get into one of the heritage buildings in Semarang, make the revitalization do not want it to change the atmosphere, façade, and the structure of the original building. As one of the cultural heritage as well as a building that is protected by the Government, Lawang Sewu from less desirable communities. Lack of promotion is done, so the popularity of Lawang Sewu defeated by shopping centers and malls are more and more in the city of Semarang causing shortages Lawang Sewu number of visitors, especially on weekdays.

Lawang Sewu not allowed to change the exterior of the heritage for it needs to be done over the function of Lawang Sewu building should return to the iconic buldings and attracted many people. Plans over the function of the building, it is necessary to explore the potential that existed at Lawang Sewu building and its surroundings, in order to become one of the landmarks of Semarang.

\section{Concept Design}

Law No. 11 of 2010 on Heritage defines heritage as immaterial cultural heritage in the form of object of cultural, heritage building, structure heritage, world heritage, and cultural reserve on land and or water to preserve its existence because it 
has important value for history, science, education, religion, and or culture through setting process. In this law is not set on "conversion" but development is described in article 78 which reads "Development of Cultural heritage carried out with due regard to the principle of expediency, safety, authenticity, and the values attached to it. Similarly the Dutch East Indies heritage of historic buildings is an asset at the same area of the building heritage which only developed utilization without changing its original from as set out in Article 95 of law 11 of 2010 that local governments have the task to the protection, development, and utilization of Cultural Heritage. The local government in making policies for the development of heritage buildings which should also consider whether the current building has given maximum productivity that is allowed to be constructed building other more valuable or with other terms should pay attention to the highest and best use, in which he must meet four criteria, physically possible, legally permissible, legally permitted, financially feasible, financially viable, maximally productive, maximum productivity (yield the highest value) (Hanafi, et. al., 2014).

\section{Redesign Plan}

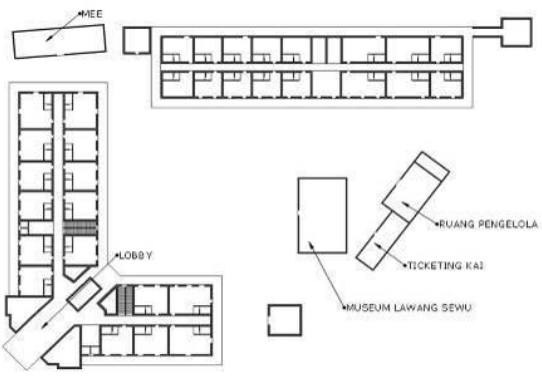

(a)

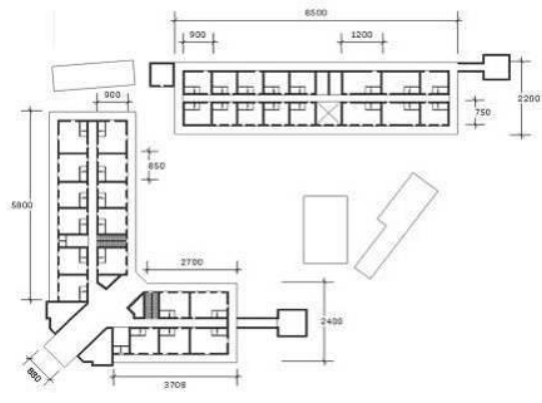

(b)

Source: (Hanafi, et. al., 2014).

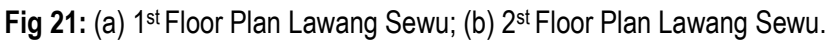
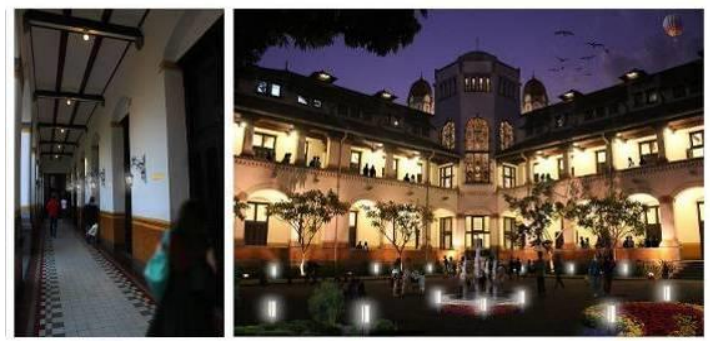

Source: (Hanafi, et. al., 2014).

Fig 22: Redesign Exterior Lawang Sewu. 

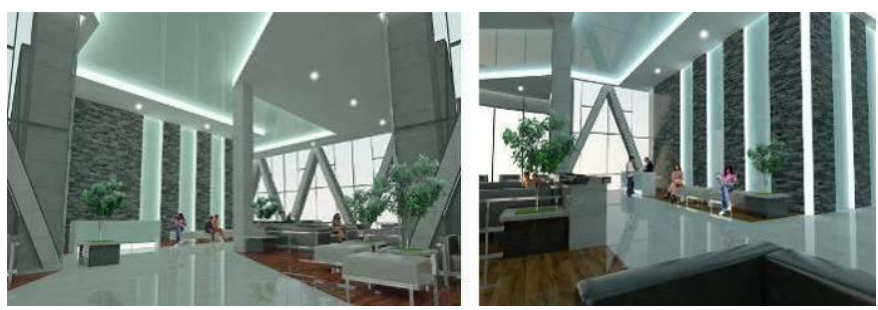

Source: (Hanafi, et. al., 2014).

Fig 23: Redesign Lobby Lawang Sewu.
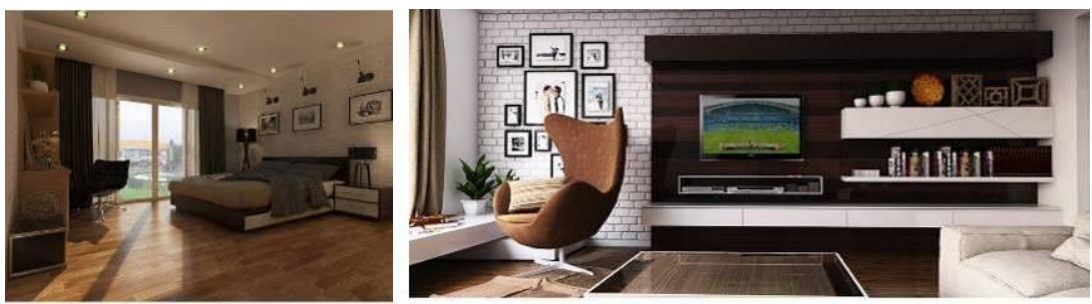

Source: (Hanafi, et. al., 2014).

Fig 24: Redesign Interior Room Lawang Sewu

\section{Conclusion}

The heritage buildings in Semarang have problems left behind by their owners, so the government finds it difficult to identify owners of heritage buildings. The heritage building was eventually damaged due to the long time not being used. To overcome this problem, Semarang City Government attempted to change the function of historic buildings and make other functions more modern without changing the previous characters and patterns. Historic buildings will change other functions depending on the investor demand and the potential that exists in the surrounding environment. With the change of function is expected to increase the tourist attraction in Semarang City.

\section{References}

[1] Darmawan. Edy. 2015. Changing Function of Heritage Building (English Edition). Surakarta: Badan Penerbit Universitas Sebelas Maret Surakarta.

[2] Bappeda. 1988. Laporan Draft Final Konservasi Bangunan dan Lingkungan Kotamadya Dati Il Semarang. Semarang.

[3] Catanese, Anthony James, James C. Snyder. 1979. Introduction to Urban Planning. New York: McGraw-Hill.

[4] Mulyandari, Hestin. 2010. Pengantar Arsitektur Kota. Yogyakarta: Penerbit ANDI.

[5] Piandel, Ageng. 2014. "Redesign Kota Lama Semarang" Urban Design 2. Semarang.

[6] Arikunto, 2006. Prosedur Penelitian: Suatu Pendekatan Praktik. Jakarta: PT Rineka Cipta.

[7] Ruci, Nadisya, Yozella Adjie, Yerikho Galih, Ratih Puspitaningrum, and Septian Nugroho. 2014. "Redesign Mberok Bridge" Urban Design 2. Semarang.

[8] Hanafi, Ali, Skolastika Anjar K, Sigit Rianto, Marett Purnamasari, and Hartini Dwi Ayu Putri. 2014. "Integrated Area at Tawang Station, Polder and KAI Building" Urban Design 2. Semarang.

[9] The President of Indonesia Law No. 5/1992 Regarding Cultural Heritage. 
